\title{
ANTINOCICEPTIVE EFFECTS OF AN EXTRACT OF SECURIGERA SECURIDACA AND THEIR MECHANISMS IN MICE
}

\author{
Received August 12, 2012.
}

We examined the effects of an aqueous extract from seeds of Securigera securidaca L. (S. s.), a plant used in folk medicine, on experimentally induced pain in balb-c mice. The tailflick test (somatic pain evoked by thermonociceptive stimulation) and writhing test (visceral pain after i.p. injections of acetic acid) were used. Three doses of the extract $(85,170,340 \mathrm{mg}$ of dry substance per $1 \mathrm{~kg}$ body mass) were i.p. injected before the tests. Significant antinociception effects were observed in both tests; a dose of $170 \mathrm{mg} / \mathrm{kg}$ appeared to be optimum. Antinociceptive effects of the $S$. $s$. extract were comparable with those of $1 \mathrm{mg} / \mathrm{kg}$ morphine. Naloxone, metoclopramide, ondancetron, and scopolamine (antagonists of opioid, dopamine, serotonin, and cholinergic receptors, respectively) completely eliminated antinociceptive effects of the $S$. s. extract in the tail-flick test; the effects of these antagonists were not so clear in the writhing test. The mechanisms of analgesic actions of the $S$. $s$. extract are discussed; the respective effects are probably related (at least partly) to the presence of flavonoids in this extract. Further investigations are necessary for adequate interpretation of the above mechanisms.

Keywords: Securigera securidaca L., nociception, tail-flick test, writhing test, flavonoids, mice.

\section{INTRODUCTION}

A number of novel analgesic drugs have been proposed within recent years. Better efficacy and fewer side effects are, naturally, expected from such pharmaceutical agents. Many researchers and pharmaceutical companies focus at present their attention on plant products for finding new analgesic means for clinical application [1].

Securigera securidaca L. (S. s.) called "gandehtalkhe" in the Iranian literature ("goat pea" in English) is a plant from the Papillionaceae family [2]. This plant has for a long time been used in Iranian folk medicine [3-5]. According to the respective studies, its seed extract demonstrates various activities, in particular hypokalemic, diuretic, antiepileptic, marked chronotropic, and hypoglycemic. The hydroalcoholic extract of this plant was reported to exert a hypolipidemic effect [6]. The antioxidant activity of this extract has also been assessed [7].

\footnotetext{
${ }^{1,2}$ Hamadan University of Medical Sciences, Hamadan, Iran ( $\left({ }^{1}\right.$ Neurophysiology Research Center, ${ }^{2}$ Student Research Committee). Correspondence should be addressed to P. Pahlevani (e-mail: pouyan.pahlevani@gmail.com).
}

Phytochemical researches showed that many potentially active components, in particular flavonoids, alkaloids, tannins, and saponins, are present in the $S$. $s$. seed extract [5]. As was found, various flavonoids provide significant antinociception effects [1, 8-10]. Flavonoids can inhibit enzymes involved in metabolism of arachidonic acid, and this suppresses pain and inflammation $[10,11]$.

Thus, there are some components in the $S$. $s$. extract that possess analgesic effects. At the same time, to our knowledge, integral antinociceptive effects of the $S$. $s$. have not been directly documented. Using standard behavioral tests, we examined antinociceptive effects of the $S$. $s$. aqueous extract in male mice and tried to estimate possible neurochemical mechanisms of such effects.

\section{METHODS}

Animals. Adult balb-c male mice weighing 20-40 g were housed in an animal house at the Hamadan University of Medical Sciences. Temperature and humidity were controlled and maintained constant 
$\left(20-25^{\circ} \mathrm{C}, 45-65 \%\right)$. All animals had access to food pellets and tap water at libitum and were maintained under a $12 / 12 \mathrm{~h}$ light/dark cycle. Experiments were performed at 9.00 to 13.00 each day and conformed to the Guide for Care and Use of Laboratory Animals published by the United States National Institutes of Health (NIH Publication No. 85-23, revised 1985).

Preparation of the Extract. The $S$. $s$. plants were gathered from the campus of the Herbal Garden in Hamedan (Iran), identified, and authenticated. The seeds of the plant were dispersed and added to hot water lower than the boiling point for about $20 \mathrm{~min}$, and the mixture was filtered. The filtrate was freeze-dried.

Tail-Flick Test. Acute somatic pain was induced via thermonociceptive stimulation by focusing an infrared beam on the middle part of the tail; a tail-flick unit was used [12]. Mice were held in the restrainer with their tail out and habituated for 2 min to the environment. The latency of flicking the tail (TFL) was measured three times for each mouse with 2-min-long rests. The cut-off time for preventing tissue injury was $10 \mathrm{sec}$. Acute antinociception effects were estimated by comparison of the data obtained before and after injections (see below).

Writhing (Acetic Acid) Test. Acetic acid (6\%) i.p. injections $(10 \mathrm{ml} / \mathrm{kg})$ were used for the induction of visceral pain manifested in abdominal contractions [13]. The animals of experimental groups were adapted at least $30 \mathrm{~min}$ to the test cage. Abdominal contractions followed by hindlimb extensions were counted for 30 min (involving three 10-min-long periods) starting just after acetic acid injection.

Drugs. Morphine sulfate (Daroupakhsh, Iran), as a generally used pain-suppressing drug, naloxone (Toliddaru, Iran) as an opioid receptor antagonist, metoclopramide (Tehran Cheime, Iran) as a dopamine receptor antagonist, ondansetron (Tehran Cheime, Iran) as a serotonin receptor antagonist, and scopolamine (Sigma, India) as a cholinergic receptor antagonist were applied in the tests. The $S$. $s$. seed aqueous extract was injected in three different doses $(85,170$, and 340 $\mathrm{mg} / \mathrm{kg}$ of the dry substance).

Experimental Groups. Nine animal groups $(n=7$ in each) were used in the tests. Three groups (2-4) received injections of the $S$. $s$. extract in the abovementioned three doses. Group 5 (Morph) was injected with $1 \mathrm{mg} / \mathrm{kg}$ morphine sulfate. Groups 6-9 $(\mathrm{Nal}+S$. $s$. 170, Ond $+S . s .170$, Met + S. s. 170, and Scop $+S . s .170)$ received the mentioned drugs (Nal, $0.4 \mathrm{mg} / \mathrm{kg}$; Ond, $0.5 \mathrm{mg} / \mathrm{kg}$; Met, $1.0 \mathrm{mg} / \mathrm{kg}$, and Scop, $1.0 \mathrm{mg} / \mathrm{kg}$ );
$10 \mathrm{~min}$ later, the extract $(170 \mathrm{mg} / \mathrm{kg})$ was injected. The Morph group was preliminarily injected with $2 \%$ saline, and the same was done in the $S$. $s$. groups. The control group 1 received $2 \%$ saline in both injections. Tests were begun in all groups 15 min after the second injection. All drugs, extract, and saline were injected i.p. in a $10 \mathrm{ml} / \mathrm{kg}$ volume.

Statistical Analysis. The Student's paired $t$-test was used for comparing the baseline and postinjection TFL values. Statistical comparisons among experimental groups were performed by one-way analysis of variance (ANOVA) followed by the Tukey test. The level $P<0.05$ was taken as significant. Data are presented below as means \pm s.e.m.

\section{RESULTS}

There were no significant intergroup differences between the TFL values before the injections (baseline TFLs). The $S$. $s$. extract demonstrated significant antinociceptive effects in the tail-flick test (Fig. 1). The $85 \mathrm{mg} / \mathrm{kg}$ dose increased the mean TFL very slightly but significantly. The $170 \mathrm{mg} / \mathrm{kg}$ dose of the $S$. $s$. extract was found to be most effective; it increased the mean TFL more than two times, but with high interindividual variability. The highest dose used $(340 \mathrm{mg} / \mathrm{kg}$ ) exerted a quite obvious antinociceptive effect but weaker than that in the previous $(170 \mathrm{mg} / \mathrm{kg})$ group. The effect of isolated action of morphine on the TFL was also quite significant but weaker than that in group 3 (S. s. 170). All blockers tested practically completely eliminated the antinociceptive effects of the $S$. $s$. extract in the optimum dose $(170 \mathrm{mg} / \mathrm{kg})$. Combined injections Ond $+S$. s. 170 and Scop $+S$. s. 170 resulted even in some shortening of the TFL, i.e., in some increase in the sensitivity to thermonociceptive stimulation (Fig. 1).

In the writhing test, all doses of the $S$. $s$. extract used in isolation provided very intense highly significant antinociceptive effects; behavioral manifestations of visceral pain (abdominal contractions and limb extensions) observed within the test period demonstrated manyfold decreases. Isolated injections of morphine nearly completely eliminated the above pain manifestations in the writhing test. Combined injections of all blockers used seemed to exert insignificant influences on the actions of the $S$. $s$. extract; there were no significant differences between the drug-injected groups and group S. s. 170 (Fig. 2). 




F i g. 1. Effects of the aqueous extract of Securigera securidaca L. (S. s.) on the tail-flick latency (TFL), sec. Light and dark columns are the mean TFL values \pm s.e.m. before and after injections of the drugs, respectively. The $S$. $s$. extract was injected in groups $2-4$ in three different doses indicated (mg/kg); in groups 6-9 it was injected in the $170 \mathrm{mg} / \mathrm{kg}$ dose after preliminary injections of naloxone (Nal), ondansetron (Ond), metoclopramid (Met), and scopolamine (Scop). Mice of the control group 1 (Contr.) and group 5 (Morph) were injected only with saline and morphine, respectively. ${ }^{*} P<0.05$, $* * P<0.01$, and $* * * P<0.001$ in comparisons with group 1 (Contr.) using the paired $t$-test and ANOVA; one, two, and three \# symbols, the same in comparisons with group 3 (S. s 170).

Р и с. 1. Впливи водного екстракту Securigera securidaca на латентний період відсмикування хвоста у відповідному тесті.

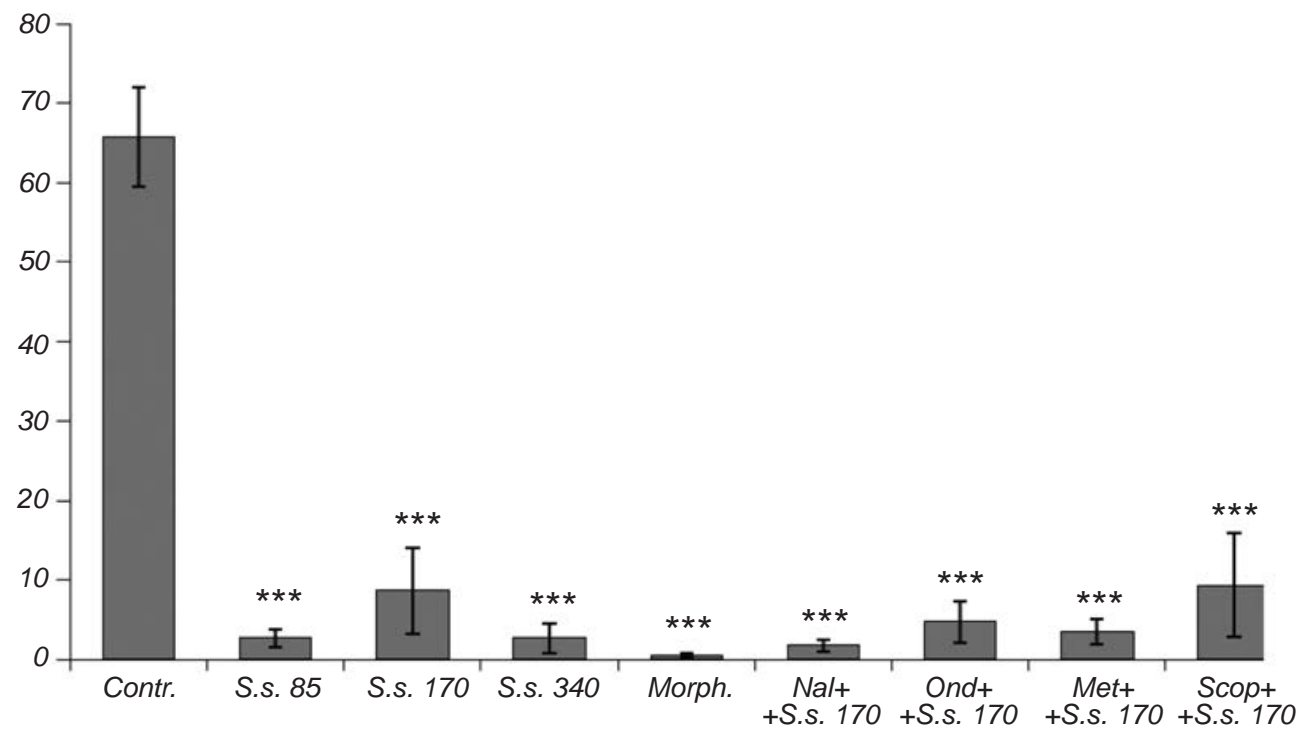

F i g. 2. Effects of the $S$. $s$. extract in different doses (applied in isolation and in combination with the drugs indicated) on the numbers of pain behavioral manifestations (abdominal contractions and hindlimb extensions) in the writhing test. The effect of isolated injections of morphine is also shown. Designations are similar to those in Fig. 1.

Р и с. 2. Впливи екстракту Securigera securidaca у різних дозах, що вводився ізольовано або в комбінації із зазначеними агентами, на кількість больових поведінкових проявів (корчів тулуба та розгинань задніх кінцівок) у „корчовому” тесті.

\section{DISCUSSION}

The problem of finding novel antinociceptive drugs with better main positive effects and lesser side effects remains extremely urgent.

Our study demonstrated that $S$. $s$. aqueous seed extract can exert significant antinociceptive effects. As we can see, the mean TFL values increased noticeably in the extract-receiving groups. The levels of antinociception showed a certain dose dependence in the tail-flick test, and a dose of $170 \mathrm{mg} / \mathrm{kg}$ of the dry extract appeared to be optimum in this test (Fig. 1). 
Naloxone and metoclopramide reduced the TFL values in the respective $\mathrm{Nal}+S$. s. 170 and Met $+S$. s. 170 groups with no significant differences between the preand post-injection tail-flick indices. Thus, it can be concluded that opioidergic and dopaminergic systems are involved to a significant extent in the effects of $S$. $s$. on acute somatosensory pain. Flavonoids are known to affect pain of different origins with the involvement of the opioidergic system [14], and the respective components have been found in the $S$. s. extract [5]. Thus, the inhibitory action of naloxone on opioid receptors might be the reason for the respective effect, but we are not sure if elimination of antinociception after blocking of dopamine receptors is related to flavonoids or some other components in the extract. It is interesting (and even strange) that combined injections of ondancetron and scopolamine with the extract made somatosensory pain more intense (reduced the mean TFLs), showing a significant difference in comparison with the respective values before injection. Additional studies are necessary to find the answer for this question.

In the writhing test, we observed clear antinociceptive effects in all extract- and drug-injected groups. Thus, the effects of the $S$. $s$. extract in the case of visceral pain differ noticeably from those in the tail-flick test (thermonociception-induced somatosensory pain). There were no significant differences between the drug-injected groups; it seems that in the case of visceral pain the $S$. $s$. extract may affect some different afferent and CNS pathways. It remains unclear why naloxone (an opioid antagonist) did not suppress the antinociceptive effect of the extract under these conditions (in contrast to what we observed in the tail-flick test). Interactions between multiple compounds present in the extract and involved in the antinociception effect of the latter and differences between the pathways of pain modulation in the case of somatic and visceral pain may be reasons for some of the contradictions in our observations.

Reduction of abdominal constrictions in the writhing test was found after the pretreatment with dihydroxyflavones [14]. There are several indications pointing to the role of the opioid system in the antinociception effects of flavonoid compounds [15-17, 14]. Also, there are some reports that serotonergic pathways can play a role in these effects of flavonoids [18]. It was demonstrated that the bioflavonoid quercetin affects the dopaminergic [19] and adrenergic [20] systems and decreases pain. At the same time, it was reported that ondansetron (serotonergic antagonist), haloperidol (dopaminergic antagonist), and yohimbine (alpha-2 adrenergic receptor antagonist) did not reverse the antinociception effects of flavonoids [14]. Naloxone did not block the antinociception effect of Polygala paniculata L. hydroalcohol extract; the latter includes a flavonoid, rutin. It was supposed that the above compound may affect pain only synergically with other compounds present in the extract [21]. Certain relationships in the molecular structure of flavonoids and opioid receptors can explain the interaction between them [22]. Naloxone and WAY100635 (a selective $5 \mathrm{HT}_{1 \mathrm{~A}}$ antagonist) prevented the effects of Rosmarinus officinalis extract in pain-induced functional impairment in the rat model (PIFIR), showing that both opioidergic and serotonergic systems play certain roles in the antinociception effect of the extract of this plant; the latter contains a flavone glycoside called hesperidin [23]. Loscalzo et al. [24] also reported that opioid receptors are involved in the antinociceptive effect of hesperidin. It should be recognized that opinions on the mechanisms of analgesic effects of flavonoids have not been finalized.

Therefore, our experiments demonstrated that the $S$. s. aqueous extract exerts significant antinociception effects, and flavonoids present in this extract may be the main reason for such an action. At the same time, results obtained with use of the tail-flick and writhing tests and also with application of certain receptor blockers are controversial from a few aspects and difficult to interpret. Thus, additional investigations are needed to make clearer the mechanisms of interaction of the components of the examined extract and their action on the main neurochemical systems.

Acknowledgments. This research was supported by a grant from the Student Research Committee, Hamadan University of Medical Sciences.

\section{С. Шахіді ${ }^{1}$, П. Пахлевані ${ }^{1}$}

\section{АНТИНОЦИЦЕПТИВНІ ВПЛИВИ ЕКСТРАКТУ SECURIGERA SECURIDACA L. НА МИШЕЙ ТА МЕХАНІЗМИ ТАКИХ ЕФЕКТІВ}

\author{
${ }^{1}$ Хамаданський медичний університет (Іран). \\ P е 3 ю м е
}

Ми досліджували впливи водного екстракту з насіння Securigera securidaca L. (S. s.) - рослини, що використовується в народній медицині, - на експериментально викликаний 
біль у мишей лінії balb-c. Застосовували тест з відсмикуванням хвоста (соматичний біль, викликаний термоноцицептивною стимуляцією) та «корчовий» тест (вісцеральний біль після внутрішньоочеревинних уведень оцтової кислоти). Перед тестами внутрішньоочеревинно ін'єкували екстракт у трьох дозах $(85,170$ та 340 мг сухої речовини на 1 кг маси тіла). В обох тестах спостерігали істотні антиноцицептивні впливи екстракту; доза 170 мг/кг виглядала оптимальною. Антиноцицептивні впливи екстракту $S$. $S$. були порівняльними 3 такими після введень 1 мг/кг морфіну. Налоксон, метоклопрамід, ондацетрон та скополамін (антагоністи опіоїдних, дофамінових, серотонінових та холінергічних рецепторів відповідно) повністю нівелювали антиноцицептивні ефекти екстракту S. s. у тесті відсмикування хвоста; ефекти згаданих антагоністів у „корчовому” тесті не були такими очевидними. Обговорюються можливі механізми аналгетичних впливів екстракту S. s.; відповідні ефекти вірогідно залежать (у всякому разі частково) від наявності в цьому екстракті флавоноїдів. Для адекватної інтерпретації зазначених механізмів потрібні подальші дослідження.

\section{REFERENCES}

1. J. B. Calixto, A. Beirith, J. Ferreira, et al., "Naturally occurring antinociceptive substances from plants," Phytother. Res., 14, No. 6, 401-418 (2000).

2. A. Ghahraman, Flore de Iranen Coulerus Naturelle, Vol. 12, Tehran Univ. Press, Tehran (1993)

3 M. Ghazi and B. Maki, "Effect of Securigera securidaca on electroshock seizure threshold in mice," Psychol. Rep., 24, No. 2, 551-553 (1969).

4. A. Ali, M. Mohamed, M. Kamel, et al., "Studies on Securigera securidacea L., Deg. et Dörfl. (Fabaceae) seeds, an antidiabetic Egyptian folk medicine," Pharmazie, 53, No. 10, 710-715 (1998).

5. H. Hosseinzadeh, M. Ramezani, and A. Danaei, "Antihyperglycaemic effect and acute toxicity of Securigera securidaca L. seed extracts in mice," Phytother. Res., 16, No. 8, 745-747 (2002).

6. A. Garjani, F. Fathiazad, A. Zakheri, et al., "The effect of total extract of Securigera securidaca L. seeds on serum lipid profiles, antioxidant status, and vascular function in hypercholesterolemic rats," J. Ethnopharmacol., 126, No. 3, 525-532 (2009).

7. M. Pouramir, M. E. Shahaboddin, A. A. Moghadamnia, and K. Parastouei, "To study the effects of Securigera securidaca (L.) seed against alloxan-induced hyperglycemia," J. Med. Plants Res., 14, No. 5, 3188-3191 (2011).

8. E. M. Choi, "Antinociceptive and antiinflammatory activities of pine (Pinus densiflora) pollen extract," Phytother. Res., 21, No. 5, 471-475 (2007).

9. G. Kekesi, I. Dobos, G. Benedek, and G. Horvath, "Antinociceptive activity of Sempervivum tectorum L. extract in rats," Phytother. Res., 17, No. 9, 1032-1036 (2003).
10. S. R. Mada, M. R. Metukuri, L. Burugula, et al., "Antiinflammatory and antinociceptive activities of gossypin and procumbentin-cyclooxygenase-2 (COX-2) inhibition studies," Phytother. Res., 23, No. 6, 878-884 (2009).

11. G. Gutiérrez-Venegas, M. Jiménez-Estrada, and S. Maldonado, "The effect of flavonoids on transduction mechanisms in lipopolysaccharide-treated human gingival fibroblasts," Int. J. Immunopharmacol., 7, No. 9, 1199-1210 (2007).

12. A. Dehpour, H. Sadeghipour, A. Nowroozi, and N. Akbarloo, "The effect of the serotonergic system on opioid withdrawallike syndrome in a mouse model of cholestasis," Human Psychopharmacol. Clin. Exp., 15, No. 6, 423-428 (2000).

13. R. Depoortere, M. Meleine, L. Bardin, et al., "Milnacipran is active in models of irritable bowel syndrome and abdominal visceral pain in rodents," Eur. J. Pharmacol., 672, Nos. 1/3, 83-87 (2011). doi:10.1016/j.ejphar.2011.09.182

14. K. Vidyalakshmi, P. Kamalakannan, S. Viswanathan, and S. Ramaswamy, "Antinociceptive effect of certain dihydroxyflavones in mice," Pharmacol. Biochem. Behav., 96, No. 1, 1-6 (2010).

15. P. Thirugnanasambantham, S. Viswanathan, C. Mythirayee, et al., "Analgesic activity of certain flavone derivatives: a structure-activity study," J. Ethnopharmacol., 28, No. 2, $207-$ 214 (1990).

16. P. Thirugnanasambantham, S. Viswanathan, S. Ramaswamy, et al., "Analgesic activity of certain flavone derivatives: A structure-activity study," Clin. Exp. Pharmacol. Physiol., 20, No. 1, 59-63 (1993).

17. S. Umamaheswari, S. Viswanathan, B. Sathiyasekaran, et al., "Antinociceptive activity of certain dihydroxy flavones," Ind. J. Pharm. Sci., 68, No. 6, 749-753 (2006).

18. A. W. Filho, V. C. Filho, L. Olinger, and M. M. de Souza, "Quercetin: further investigation of its antinociceptive properties and mechanisms of action," Arch. Pharmacol. Res., 31, No. 6, 713-721 (2008).

19. P. S. Naidu, A. Singh, and S. K. Kulkarni, "D2-dopamine receptor and $\alpha 2$-adrenoreceptor-mediated analgesic response of quercetin," Ind. J. Exp. Biol., 41, No. 12, 1400-1404 (2003).

20. R. Kaur, D. Singh, and K. Chopra, "Participation of $\alpha 2$ receptors in the antinociceptive activity of quercetin," J. Med. Food, 8, No. 4, 529-532 (2005).

21. L. R. Lapa, V. M. Gadotti, F. C. Missau, et al., "Antinociceptive properties of the hydroalcoholic extract and the flavonoid rutin, obtained from Polygala paniculata L., in mice," Basic Clin. Pharmacol. Toxicol., 104, No. 4, 306-315 (2009).

22. P. L. Katavic, K. Lamb, H. Navarro, and T. E. Prisinzano, "Flavonoids as opioid receptor ligands: identification and preliminary structure-activity relationships," J. Nat. Prod., 70, No. 8, 1278-1282 (2007).

23. A. L. Martinez, M. E. González-Trujano, M. Chávez, et al., "Hesperidin produces antinociceptive response and synergistic interaction with ketorolac in an arthritic gout-type pain in rats," Pharmacol. Biochem. Behav., 97, No. 4, 683-689 (2010).

24. L. M. Loscalzo, C. Wasowski, A. C. Paladini, and M. Marder, "Opioid receptors are involved in the sedative and antinociceptive effects of hesperidin as well as in its potentiation with benzodiazepines," Eur. J. Pharmacol., 580, No. 3, 306-313 (2008). 